\title{
China - Pakistan economic corridor: a harbinger of economic prosperity and regional peace
}

\author{
Ambreen Khursheed $^{1 *}$, Syed Karrar Haider ${ }^{2}$ (D) Faisal Mustafa ${ }^{1}$ (D) and Ayesha Akhtar ${ }^{1}$
}

\author{
* Correspondence: ambreen \\ khursheed@ucp.edu.pk \\ ${ }^{1}$ UCP Business School, Faculty of \\ Management Studies, University of \\ Central Punjab, \\ 1-Khayaban-e-Jinnah Road, Johar \\ Town, Lahore, Pakistan \\ Full list of author information is \\ available at the end of the article
}

\begin{abstract}
Provincial connectivity and growth are connected to visualization of mutual progress and economic development. This is the viewpoint behind the establishment of China-Pakistan Economic Corridor (CPEC). Developing new transport infrastructure, Gwadar Port Projects and several energy generating projects, are one of the key projects of CPEC, "All Weather Strategic Friendship" is therefore proved for Pakistan and China. China's pilot project of "Belt and Road Initiative" is the key plan, which led to the development of CPEC. It is expected from CPEC that it will reduce the transportation cost of China by providing a shorter route for China's trade to Persian Gulf and it will provide a solution to the energy shortfalls in Pakistan. Moreover, CPEC's projected prospects of economic advancement, there are some economic, security and political threats in Pakistan. This paper proposes to illuminate the significant Geo-strategic importance, opportunities and challenges for China Pakistan Economic Corridor, and it envisages to broaden the base, by including energy rich, Tajikistan economic role model Turkey and strategically located Iran. Hence, this paper provides a holistic view of previous researches on the planned subject and is not involving any data analysis as existing researches had used for analyzing a review of prospects and challenges.
\end{abstract}

Keywords: Strategic friendship, Silk road Economic Belt (SREB), South Asia

JEL classification codes: R11, R12, Q1, L51

\section{Main text}

Transportation plays a key role in developing a country. Pakistan and China share an evergreen friendly relationship and are most trustworthy and all-weather friends known as iron brothers (Sial 2014; Tharoor 2015). A new era of regional and economic diplomacy has been raised with the initiative of China's pilot project of "Belt and Road Initiative" covering Asia, Africa and Europe (Lim 2017). Ways of mutual progress between Southeast Asia and south Asia were unlocked in May 2013 when an Economic Corridor was envisioned by China's Premier Li Keqiang for Pakistan and China's shared benefit, when he visited to Pakistan (Sial 2014).

Though the imagination transformed into feasible plans and agreements in 2015, when both the countries joined hands by signing a MoU and extremely important fifty-one agreements to display their boosted cooperation for collective economic 
growth (Bhattacharjee 2015). Chinese President shared his views on the event that "I come here for the first time, but it seems that I am in my own brother home" (Tharoor 2015). Furthermore, he explained that the key project of Belt and Road Initiative is created to resuscitate the conventional trading routes extending from Asia to Africa and Europe. The president of China Xi Jinping depicted his nation as the "guardian of globalization" in comparison the US and European nationalism.

The geostrategic position of Pakistan has been one of the key reasons in selecting Pakistan as an optimal choice for developing economic corridor with China (Nogales 2014). One of its sides is shared with non-coastal countries and the other is shared with oil producing countries. Furthermore, Pakistan is bounded by hot water Arab sea, two significant evolving economies China and India, and also by Iran which is world's second largest natural gas and fourth largest oil producer country (Bilal 2014).

Hence, this project connects Pakistan and China with not only to their neighbor countries but also to more than 60 countries. Through CPEC, Chinese President Xi Jinping has attracted a huge attention for introducing a special mode of globalization (Fallon 2015). Xi Jinping has prepared this project a cornerstone of China's domestic economic strategy and foreign policy (Dent 2016). This transportation corridor aims to promote the economic incorporation, regional connectivity, and development of promising economic zones (Hancock 2017). Furthermore, several Energy, Hydro, Nuclear, Coal and solar power projects of 21,690 MW, formation of many economic zones, improvement of Gawadar seaport and International Airport are key projects of CPEC (Mangi and Haider 2015). CPEC a renowned project of "Belt and Road Initiative" that aims to benefit $66 \%$ of world population including Europe, Asia and Africa. CPEC is not only an influential project.

China has a huge potential in terms of investment and bilateral trade that could prove beneficial for developing strong economic terms with Pakistan. From recent years China has proved itself as Pakistan's biggest trading partner in terms of trade (Beenish 2013). Recently on a three-day trade fair, Li Yang, the vice director of the Division of Foreign Trade Development announced that the bilateral trade between both the countries has reached 4 billion U.S. dollars threshold (Liangyu 2018). However strong economic relations amid the two countries were proven since January 1963, President Ayub's era, when a bilateral long-term trade-agreement was signed (Peter-Brunner 2013). Both the countries share a robust relationship not only in the area of trade and economics but also in the area of peacekeeping strategies (Yogesh 2013). For ensuring private and public investments and agreements, both countries have exchanged frequent high-level visits (Muhammad and Qi 2015). This partnership between two countries is generally recognized as "allweather friendship" and has faced many obstacles since its commencement (Siddiqui 2017). Some of the most prominent issues are the imbalance of wealth between Pakistan and China (which comprises of lack of foreign exchange reserves in Pakistan), the threatening security situation in Pakistan and the imminent existence of India on both Pakistan and China's borders (Memoona et al. 2014).

However, assessing superficial goal of linking China's northwestern Xinjiang region to Pakistan, it is difficult to ignore the issues related to the geographical location and physical topography of Pakistan-China border region (Tiezzi 2014). Specifically, the 
Karakoram Highway was built with great exertion between 1959 and 1979 passes through an earthquake zone and a geopolitically sensitive mountain terrain, which is claimed by India (Syed et al. 2014). In addition to this, the poor condition of Pakistan's infrastructure in terms of energy shortfall and the lack of financial resources demand by Pakistan raises uncertain economic effects and doubts related to the ability of Pakistan for repayment of loans (Mezzera and Marco 2011).

\section{Significance of the study}

In view of existing literature, it is essential to enhance the knowledge regarding the internal instability of politics and security in Pakistan. However, the external response in context of CPEC development is still not clearly determined. This study is therefore proposed to be a complete empirically grounded study based on detailed analysis of the data focusing on the positive as well as the negative effects of the economic viability of constructing the CPEC project. The study also aims to analyze the opportunities, strengths and weaknesses which are associated with the CPEC project. As it was difficult to unpack the complication of issues regarding the feasibility of establishing a land corridor between Xinjiang and Gwadar by using only over-optimistic local media report and official announcements. Information is therefore acquired from in-depth examination of primary sources like the official CPEC website and the Gwadar Port Operating Authority website.

This study thus begins with an extended evaluation of the background with a primary focus to evaluate the feasibility of CPEC (transportation corridor) using reasonably thorough investigation of the primary and secondary data available regarding China's involvement in Pakistan.

\section{Problem statement}

At present, CPEC project is in the public eye. China and Pakistan share a unique bond of association due to their systematic compatibility and cultural openness. A huge number of researchers are working on OBOR project and its effect on developing countries. Though, very few studies have focused to analyze the economic viability and practical worth of CPEC project, and this study aims to bring into the limelight the key issues and prospects of CPEC along with the future oriented tactics.

\section{Research objectives}

Theoretically, this study is focused to determine the following research objectives.

- To assess the importance of CPEC in context of China and Pakistan economy.

- To understand what CPEC is and to examine its concealed rationale.

- To discuss the proposed opportunities and challenges which are expected from CPEC for Pakistan and China.

\section{Literature review}

\section{Economic corridors}

The main idea of economic corridors is initiated from the concept of transport corridor. A transport corridor is a network within one country or between any two countries to 
connect economic centers (Khan 2015). When their corridors extended to cover regions benefit of increased investment and multilateral trade can be witnessed. However, a great deal of effort and infrastructure is required for retaining and improving such transportation networks. Therefore, a transport corridor mainly concentrating on upgraded infrastructure is established as an Economic Corridor (Arif 2015).

Among countries' markets, the economic corridors serve as a base for networking among demands and supplies of products or services. There are no strict regulations for defining economic corridor, as each economic corridor varies in terms of its geographical position, its execution and expansion (Peter-Brunner 2013). In an economic corridor, there are four different progressive stages, in which every former stage is included to the succeeding one using a more radical approach. It generally starts with infrastructure development and transport and then it moves to logistic corridors. Thus, transport corridor provides the foundation block for the latter stage corridors to come up. Logistic corridor then joins itself in the trade corridor. A trade corridor leads to develop economic corridor which consequently results in improving economic growth (Nogales 2014). The friendly relations between Pakistan and China are moving around four mutual areas geostrategic fears, energy security concerns, economic collaboration and security concerns (Mezzera 2011a, 2011b).

\section{China Pakistan economic corridor (CPEC)}

The literature which has shown up since the official declaration of China's investment in Pakistan in April 2015 appears to share common findings and that is positive impact of joining Gwadar and Xinjiang on both economies (Javaid and Jahangir 2015). Past researchers found that from 1970s onwards, the relationship between China and Pakistan fortified more among all the sectors (Shah 2015). This was largely due to commonality of ideologies between the two leaders of the countries. Similarly, it was proved that during that period in which sanctions was imposed by US, China had liberally supported Pakistan in nuclear program, missile, military and in the economic sector as well (Wolf 2012). This flourished the confidence of building a strong relationship between Pakistani and Chinese policy makers. Consequently, this strong friendship transformed into a huge achievement in the form of China-Pakistan Economic Corridor (CPEC) (Wolf 2016).

China has been operational since decades to reestablish its gone splendor (Chaudhri 1987). For this purpose, China is constructing its prominent role in Asia and worldwide for political, social and economic collaboration through Belt and Road Initiative's project (Wang 2015). Initially, China operated with some Non-Allying countries and steadily improved its role (Jain 1981). China also stayed neutral in international affairs and concentrated on the gradual economic development (Javaid and Jahangir 2015). The first stage on its way was provided by President Xi, who started "Constructive Engagement" policy. For this purpose, a prime focus was given on the Economic engagement to enhance the constructive plan of Naval bases and Development Bank among different countries are being mentioned as instances (Vaughn and Morrison 2006).

The Development Bank and the Creation of Asian Infrastructure is considered as modest to prevailing monetarist system and power of USA in the international financial segment (Xu 2015). In addition to this, a series of Sea ports including Burma, Bangladesh, Pakistan and Sri Lanka known as String of Pearls has been taken as a huge 
strategic venture to restrict India (Kabraji 2012). It is said that "Your enemy's enemy is your friend". Though, China is moving ahead by now primarily focusing on CPEC as a strategic transportation corridor. It has now become one of the most debated matters nationally and internationally.

$\mathrm{CPEC}$ is a complex aggregation of several transportation and energy projects comprising of $3218 \mathrm{KM}$ route including infrastructural projects, pipelines, economic free zones, Railways, and Highways between Pakistan and China (Shah 2015). The key concept behind CPEC is One Belt One Road (OBOR) strategy of China which comprises of Silk Road, Economic Belt, and twenty-first Century Maritime Silk Road. OBOR's significance with the incorporation of twenty-first Century Maritime Silk Road and China Road Economic Belt has taken its roots from the aspiration to get free trading of economic factors, improved integration among countries' markets and wellbalanced economic collaboration (Reform 2015).

$\mathrm{CPEC}$ is also playing a crucial role for bringing regional peace as Huasheng (2016) reported the impact of China's effective diplomacy on Afghanistan by documenting two aspects. First, as CPEC is considered a pilot project of "Belt and Road Initiative", China showed active interest in Afghanistan particularly from the perspective of transport. Now Afghanistan will be acting as a transport walkway for China. Second aspect focuses on the departure of US military forces and also the International Securities Assistant Forces from Afghanistan in the period of 2014. This time was a provisional period for Afghanistan. Due to CPEC project China took a step forward and exhibited a great responsibility towards Afghanistan by having official visits there along with bilateral aid. In addition, Beijing purposefully initiated the harmonization of peaceful talks between the Afghan Government and Taliban. Likewise, Seerat (2019) analyzed the role of China in assisting Afghan Taliban peace talks. He found that due to CPEC project several representatives of Shanghai Cooperation Organization in Afghanistan are in the favor of China's negotiation towards peace talks. Further, Dhaka (2014) reported that China plans to make huge investments in Central Asia region in the sector of energy and transport. Therefore, China is now more actively concerned with peace talk initiatives in Afghanistan. Further, Dhaka (2014) reported that China plans to make huge investments in Central Asia region in the sector of energy and transport. Therefore, China is now more actively concerned with peace talk initiatives in Afghanistan.

This corridor is not only a roadway, somewhat it is a consolidation of multidimensional projects (Rizvi 2013). The estimated budget of CPEC is US \$60 Billion and it includes US \$18.1billion as domestic share (Team 2015). It is projected that CPEC will supposedly resolve $80 \%$ electricity shortfall in Pakistan. It is also predicted that CPEC will create 700, 000 jobs and will ultimately reduce unemployment in Pakistan. However, any vagueness in terms of interest rate and payment terms can cause immeasurable issues in the smooth working of CPEC developmental projects (Wheeler 2017; Mustafa et al. 2018).

\section{Methodology}

In order to achieve the key objectives of this study, our methodology consisted of interpretive view with focusing on the strategic and social aspects of CPEC project. The research is deductive in nature as the economic, political, and security related aspects are reviewed for analyzing the stance and situation of Pakistan and China. This research 
examines the data which is qualitative and narrative in nature and it is obtained from the credible secondary sources consisted of official documents, academic studies, and social media which emphasized the geographic significance and the deliberate impact of CPEC. In this study longitudinal time frame is used. In order to achieve the objectives of this study, exploratory research methodology is used with the purpose to enhance the understanding and exposing the strategic worth of CPEC in context of Pakistan and China.

\section{Results and discussions}

\section{Evolving triple axis}

The most powerful five nuclear powers (Russia, China, the US, Pakistan, and India) have maintained their balance in the emerging economy through different strategies. Amongst them, the three - Russia, Pakistan, and China have been forming an alliance against the intensifying Indo-US reunion (Zhang 2015). It is an undeniable fact that, the Asian continent comprises of many geostrategic divisions. Similarly, in visualization of the Asian Century dream, India is also playing the major role of one of the progressive economic giants (Ali 2016).

Past researches have shown that Russia shares a cordial economic, political and military relationship with India specifically during cold war period (Kumar and Chopra 2009). Russia has operated as the main supplier of arms equipment to India as well (Rasul 2014). Though, after Moscow's decision on September 24, 2016 to organize joint military regulating exercises with Pakistan has caused a new paradigmatic shift of increasing Russia's interest toward Pakistan and China (Zubacheva 2016). Thus, Russia came closer to Pakistan as a reactive measure to growing Indo-US ties. An evidence of this alliance is the signing of North-South gas pipeline agreement of US $\$ 2$ billion and a landmark defense agreement for providing 'Hind-E' attack helicopters to Pakistan in 2015 (Dawn 2015). Hence, reports have revealed Pakistan's approval for Russia to become a part of economically important project, CPEC as well (Zaki 2014). By including Russia into the project, it will kill two birds with one stone.

Therefore, the Sino-Pak bond has become more concrete due to Russia's recent reconciliation with them. Ultimately, the persistent Sino-US resentment broadens with the joining of Russia in the group of Sino-Pak (Tsan 2012). Consequently, India also must adjust itself in the evolving South Asian geopolitics (Yang and Siddiqi 2011). Hence, India must monitor the promising Sino-Pak relationship alongside with the development of Triple alliance. Likewise, India must maintain its enhancing commercial and economic exchanges with China. Hence, India must retain a tactful position in order to reserve Russia's confidence (Malik 2012). Thus, the powerful game of politics has taken control of entire South Asian region.

\section{MoU signed for Pak-China economic corridor}

The MoU is signed with the aim to assist the respected economies for confirming amplified economic activities. It anticipates establishment of the mutual beneficial plan of the project up to 2030. In accordance to the MoU, Ministry of Planning and the Development and Reform (MPD\&R) is titled as NDRC - Focal Ministry of 
Pakistan, National Development and Reform Commission of China as its equivalent (Ministry of Planning, CPEC).

NDRC developed a formal body at a ministerial level named as Joint Cooperation Committee (JCC) for evolving and confirming several growing plans of Energy, Gwadar Projects and transport infrastructure between the both countries for assisting the vision of Pak-China economic corridor. JCC is focused to ensure continuous supervision of operational activities; its members are selected by nomination from the two countries (Ministry of Planning, D. A. 2015).

\section{CPEC ventures}

The proposed ventures under CPEC are characterized into three stages, the short term projects are known as Early Harvest Projects which are envisioned to be accomplished till 2017, the medium term projects are envisioned to be accomplished by 2025 and the long term plans by 2030 (News 2014). CPEC's range is not only restricted to short term projects but it also includes various long-term projects (Khan 2015).

\section{Geostrategic dynamics}

China's desire for CPEC has taken its roots from the purpose to improve its trade activities with diverse world regions'. This visualization was displayed in 2013 by Chinese President Xi Jinping who highlighted the promotion of trade network which connects China to Europe and Central Asia over three key corridors by northern, southern and central Xinjiang and it connects China to Pakistan and Russia to Europe. On the similar lines, China has now highlighted the importance of developing Bangladesh-China-India Myanmar corridor that could connect non-coastal province of China "Yunnan "to the Bengal's harbor (Chowdhury 2013).

\section{Importance for China}

The Middle East has more than half of the world's oil reserves and also it is one of the top suppliers of crude oil to China. Currently, transporters drag over around 10,000 nautical miles to the stations alongside southeast and China's east shore. Each journey is affected by the most precarious checkpoints at Passage of Malacca (Cherng and Ouyang 2013). Through CPEC, China will have an easy entrance in the Middle East, and other dominant regions having huge oil supplying markets. As currently, China is a dependent on these areas for its oil requirements. Thus, this corridor will provide an opportunity to China's industrialists and private sectors to connect with the world's fastest emerging economy via Pakistan. In this way, China can make optimal use of technology advancements in escalating collaboration for exploring mineral resources, biological resources, and other regions to promote China's significant manufacturing structure, to stimulate free-trade zone business effectiveness and to maintain its phenomenal economic growth, as energy makes the industry go (Irshad 2015). As the CPEC route is placed in a very remote area leading to huge benefits for both Pakistan and China. China's wester most cities and closest cities to this route will get economic advantages in the form of cheap labor, land supplies and natural resources. Therefore, $\mathrm{CPEC}$ is considered as a difference maker for enhancing China's economic flourishment and BRI project. Further, this project will provide China access to the Kashgar 
special economic zone and the Indian Ocean. This will ultimately transform these regions into inland ports for connecting the oceans therefore re-creating the Shenzhen miracle and forming the engine of China's second great development era. Xinjiang and Tibet are China's inherent territories on which the government has full dominion. Thus, as long as western China acquires access to the Indian Ocean, it will surely take benefit of the surplus capital for supporting those areas in which funding is required for development purposes. In this way, CPEC will play a key role in decreasing the developmental gap between Chinese western and coastal cities.

Moreover, because of Pakistan's cordial relationship with Middle East Muslim countries, through this project China will develop an excellent base for future. In addition to this, the profit acquiring percentage is heavily in favor of China as compared to Pakistan as she believes in investment not in invasion.

\section{Importance for Pakistan}

China is not only the second largest trade companion of Pakistan but also a huge investor in telecommunications, energy sectors, ports and infrastructure. Moreover, to promote mutual trade, Chinese government and private sectors have confirmed US $\$ 20$ billion investment in energy sector and $\$ 30$ billion in the other key sectors as FDI (foreign direct investment) in Pakistan. The CPEC has made Pakistan first transfer hub of world's leading economy amongst all South Asian countries (Memoona et al. 2014). Despite all military and political barriers of this project, it still has many advantages for whole nation. Currently, Pakistan is facing major energy shortfalls and constricted trade with its abrupt neighbors, will have improved trade relations and will become energysufficient country. The CPEC will simplify movement of goods and services in the key trade regions, will transform rivals into stakeholders to preserve stability and peace in the Central Asian and South regions. Thus, CPEC will boost Pakistan's economy against rival India.

CPEC will also connect Pakistan to a country that is the hub of natural resources, Tajikistan, formerly it was a part of Soviet Union, having a population of 7.5 million and an area of $143,100 \mathrm{~km}^{2}$. This country shares her borders with China, Afghanistan, Uzbekistan, and Kyrgyzstan. The Wakhan Corridor separates it from Pakistan in the area of Afghanistan. With the development of CPEC, Pakistan through Gilgit-Baltistan will have access to Tajikistan as well. Therefore, Gilgit-Baltistan will connect Central Asia and China leading to successful geo-economic future of Pakistan (Khan 2018).

\section{Increase in revenue from transport infrastructure}

The transportation project "CPEC" is aimed to import and export from Gawadar to China and China to other key regions, in this way Gawadar port will operate as significant transit hub. Railway and Highway network comprises of the construction of Karachi-Lahore Motorway, Thakot to Havalian KKH Phase - II (45 M US \$) and improvement of Karachi-Lahore Peshawar (ML-1) Railway Track (1872 kms). A fiber optic cable project is also designed for enhancing international communication networks from China to Islamabad and approximately $85 \%$ of the total funding ( $\$ 44$ Million) is given by China and it is anticipated to be finished within 3 years. Similarly, several Oil and Gas projects are also signed, and the revenue anticipated from Oil and 
Gas projects is around US\$1,000,000 (Haider and Haider 2015). A recent report has claimed that CPEC will become active in 2019 and will generate revenue from around from 1.5 billion to 1.9 billion US\$ and will range to US\$ 5 billion in 2022 (Disk 2017). Such huge amount of revenue will economically fortify Pakistan.

\section{Energy projects}

On 8th November 2014 an agreement for evacuating energy crisis in Pakistan was signed by both the countries. Its first set comprises of 14 ventures of 10,400 MW to be finished by 2017/2018 and is entitled as "Prioritized Projects". The second set comprises of seven ventures of $6645 \mathrm{MW}$ to be finished by 2018 and is entitled as "Actively Promoted". Though, there is a blend of three types of Energy and Power Plans which includes various power generating plans; coal-fired plant for generating power at Port Qasim and in Sahiwal of 1320 MW, Quaid-e-Azam Solar Park of 1000 MW, Wind power station at Jhimpir of $100 \mathrm{MW}$, Imported Coal Based Power station at Gwadar of 300 MW, Thar Block II Coal-Fired Power Project of 1320 MW and Sindh's coal mining project of $660 \mathrm{MW}$, Punjab Solar Project of $300 \mathrm{MW}$, Dawood Wind Power Project of $50 \mathrm{MW}$, Karot hydropower station of $720 \mathrm{MW}$, Hydropower project of Hydro-Electric Suki Kinari of $870 \mathrm{MW}$, and a contract for Salt-Range coal-fired power project (Shehzad 2018; Ramachandran and Linde 2011).

\section{Economic impact of CPEC}

The CPEC is a transport route between Pakistan and China with approximately $2700 \mathrm{~km}$ long roadway, rail, oil and gas pipeline (Nan 2015). CPEC aims to strengthen the economic ties between China and Pakistan. This safest and shortest route will replace current Chinese lengthy route $(12,500 \mathrm{~km})$ which will reduce time and huge amount of shipping expenses for China's trade to Persian Gulf and with entire world (Khan 2013). The key objective of CPEC is to lift the economy of Pakistan and to enhance Pakistan's infrastructural and social development and on the other hand it will boost trading and investment activities with China and all over the world by giving a safest and shortest optimal replacement of Malacca. Among countries, the improved logistics, upgraded infrastructure progress and enhanced transportation system are extremely important for economic well-being. (De and Iyengar 2014). Hence, CPEC will play a significantly important role for the whole economy (Ali 2016; Ali et al. 2017).

\section{Challenges and threats for Pakistan}

Despite of expected significant advantages of CPEC, Pakistan is dealing with many difficulties to implement this project. These threats are internal as well as external. Firstly, it is feared that Pakistan can relapse into colonization changing its masters in the process. Secondly, it is anticipated that because of its huge size and economic ascendancy the bilateral trade might tilt in favor of the economically robust partner. But the silver lining is that till now China has never been found to indulge in annexing other states' land and not casting aggressive eyes on its neighbors. These challenges/threats are as below. 


\section{Concern of India}

In terms of economic and political challenges, CPEC is considered as a biggest threat to its neighboring country, India. As reported by Blah (2018) India has expressed serious concerns regarding Belt and Road Initiative (BRI) project. Although, China actively invited India to become a participant in Belt and Road Summit held in Beijing, but India expressed a negative response due to the involvement of Pakistan Occupied Kashmir (POK) area that is a very delicate issue between India and Pakistan. India considers this project as a sign of harm to its sovereignty. India also has a viewpoint that the strategic control of Indian Ocean will be captured by China through this smokescreen project called by India. Further, India's security control in the region is also one of the major concerns regarding CPEC. China expresses to involve India as an acceptance of its success in Central Asia. But, India resolutely holds that this association must bring territorial integrity and respect for sovereignty (Durrani 2013).

\section{Ethnic and religious parties differences}

From the perspective of provincial government and religious parties ruling in Pakistan. Several parties have expressed severe concern regarding CPEC project. As Hameed (2018) disclosed that KPK government announced that CPEC project is not concerning the prioritization of Eastern route. They also passed a resolution in the opposition of any route shift. However, the problem arises as the original route was supposed to nourish under-developed areas of KPK (Ahmad and Hong 2017; Mengal 2016;). Aftab Ahmed Sherpao, leader of the Qaumi Watan Party expressed the concerns of his party that government claimed to provide 10,000 MW electricity into the national grid holds and the government is preferring Punjab over other provinces. While all the other provinces possess a weak power distribution system. Therefore, the increase in the energy production will not prove beneficial for the marginalized provinces (Raza 2016). Gilgit-Baltistan also demanded a huge share in CPEC project by doing protests (Ali 2016). Resultantly, the government responded to the protests by repeatedly declaring that CPEC will prove beneficial for all the provinces in equal ways. However, due to the lack of transparency in government initiatives, these opposition and fears may stimulate.

\section{China and North Korea}

China's support for its ex closest ally North Korea started from the Korean War (19501953), when its military troops entered the Korean Peninsula to help its northern partner. As Beijing and Pyongyang ideological similarity strengthens bilateral alliance (Byman and Lind 2010). China provided huge amount of energy and food supplies to North Korea which covered over $60 \%$ of its entire trade volume and accounted for approximately $90 \%$ of its energy imports (Park 2011). Since that time, China aided economic and political support to the North Korean leaders. Hence, North Korea had significant economic reliance over China. Their relationship was significantly apparent, since both shared key strategic challenges to the US and possessed the considerable conventional armed forces with booming ballistic missile projects as well (Lee 2012). On the other hand, South Korea has proved to be under the influence of US shares a cold shoulder with North Korea (Stares and Wit 2009). 
However, strains in their liaison began to appear when Pyongyang experimented a nuclear missile in 2006. As, China supported UN Security Council resolution of 1718, which enforced sanctions on Pyongyang. After this, Beijing indicated a shift in its tone from diplomacy to penalty, which it maintained after Pyongyang's second nuclear test in 2009. After third Pyongyang's nuclear experiment in 2013, Beijing became harsher in approach and summoned North Korea and after this they turned their backs on the North Koreans (Choi and Shaw 2010). Similarly, now Pakistan's increasing economic dependence on China is of huge worry as one-day China might do the same with Pakistan because there is no guarantee that China will not resist any military activity of Pakistan.

\section{Security issues}

At the internal and external level, the major risk is of security issues. As, Pakistan is dealing with the severe terrorism and extremism issues, therefore the key political parties which are against the CPEC project are Tehreek-e-Taliban (TTP), Balochistan Liberation Front (BLF) and Daesh (ISIS). Similarly, several international agencies are also against this project and are supporting these parties by assisting them to use terrorist elements to hinder Xinjiang to Gwadar port (Khan 2015). On the other hand, few leaders of provincial political parties have argued that Punjab Province is given preference over underdeveloped cities of KPK and Balochistan (Dawn 2014).

\section{Issues of Balochistan with CPEC}

In terms of area, Balochistan is the largest province of Pakistan and it is the smallest in terms of residents. When compared over socio-economic stability of other provinces, Balochistan is the most underdeveloped province. Balochistan is one of the main trade routes through which water port of Gwadar will be connected to Kashgar city (Bhutta 2015). Since beginning of CPEC project, Balochistan has stayed a disputed zone, the Balochistan's local insurgents consider CPEC as a threat to their sovereignty as they believe that if their province would become urbanized and stable then outsiders would take over their hold. Consequently, Baloch extremists have shown their hostility by attacking on trains, gas pipelines and killing Chinese engineers (Ahmad 2015).

\section{Power tariff and tax issues}

China has expressed its concern over tax issue, electricity price and power tariff with Pakistan besides the CPEC's energy venture with Pakistan. China has depicted serious objections over delaying strategies being used by Federal Board of Revenue (FBR) (Jabri 2015). In view of agreements, all the imported equipment will be exempted from tax. Though, the approval procedure of FBR is inefficient which is negatively affecting the projects timelines in Pakistan. The government of China has also highlighted that the reduction in tariff for renewable energy will have a negative effect on CPEC project (Rind 2013).

\section{Conclusion}

This study has highlighted the critical issues and advantages of the CPEC, which is considered a part of String of Pearls strategy of China. Past researches emphasized the 
significance of CPEC and highlighted that this project could become a game changer in Asia (Ritzinger 2015; Yogesh 2013). Several studies also narrated that CPEC will convert Pakistan into a business hub and will facilitate trade with Indonesia, Bangladesh and Burma (Kostecka 2011). Thus, CPEC is transforming into a ray of hope for collaboration between not only Pakistan and China but also among economically important countries like Afghanistan, Iran, and Turkey who wish to join this project. Commencing an economic cooperation among these countries will assist resolution of several matters and fortify peace in the whole economy (Durrani 2013; De and Iyengar 2014). The relationship of Pakistan-China shares an exclusive stability for mutual benefits and collaboration that has weathered variations in the arena (Jinchen 2016). This relation has multiple dimensions often considered as a strategic relation. Though, in existing situation, there is a rising need to transform this mutual relation beyond labels and if so required, reanalyze its tactical proportions in consideration of new authenticities on the ground (Beenish 2013).

The CPEC may have positive effects so far however, its eventual success is subject to its capability towards regionalization and enhancement of its regional association. For this purpose, it is necessary that CPEC should be indulged with the energy sector, trade hubs, and road networks beyond Pakistan and China bond (Holmes 2013). Hence, despite many security and political challenges, analysts have the view that this project would reduce unemployment from many underdeveloped areas of Pakistan specifically Balochistan and KPK. However, in order to fully utilize the economic benefits from this project Pakistan must proficiently deal with all challenges. Mainly, the tax and tariffs reservation of Chinese officials must be resolved. Currently, Pakistan is dealing with terror on many fronts. In such conditions, it is difficult to maintain the sustainability of multibillion-dollar economic corridor. The violence and security threats against the project can delay the successful implementation of the project.

Thus, the study concludes that in view of Sino-Pakistani Economic Corridor, both the countries shouldn't only bound to mutual beneficial relations, however they should consider it with an international vision. In this regard, Pakistan should take serious measures to ensure safety and security of officials involved and projects related personnel and this finding is also supported by past research studies (Khan 2018; Shehzad 2018; Nogales 2014). Hence, CPEC can transform the unstable economic situation into a stable and peaceful region and can boost world development by connecting both countries through subsidiary connections originating from Punjab and Kashmir.

Abbreviations

BLF: Balochistan Liberation Front; BRI: Belt and Road Initiative; CPEC: Chine Pakistan Economic Corridor; FBR: Federal Board of Revenue; FDI: Foreign Direct Investment; JCC: Joint Cooperation Committee; MoU: Memorandum of Understanding; MPD \& R: Ministry of Planning and the Development and Reform; NDRC: National Development and Reform Commission; OBOR: One Belt One Road; POK: Pakistan Occupied Kashmir; TTP: Tehreek-e-Taliban

Acknowledgements

None.

Authors' contributions

AK worked on the overall structure of the paper. SKH, FM and AA worked on the analytical discussions stated in the paper. All authors read and approved the final manuscript.

Funding

Funding is not applicable for this study. 
Availability of data and materials

Data sharing is not applicable to this article as no datasets are generated or analyzed in the current study.

\section{Competing interests}

The authors declare that they have no competing interests.

\section{Author details}

${ }^{1}$ UCP Business School, Faculty of Management Studies, University of Central Punjab, 1-Khayaban-e-Jinnah Road, Johar Town, Lahore, Pakistan. ${ }^{2}$ Faculty of Information Technology, University of Central Punjab, 1-Khayaban-e-Jinnah Road, Johar Town, Lahore, Pakistan.

Received: 14 March 2019 Accepted: 18 October 2019

Published online: 21 November 2019

\section{References}

Ahmad, R., and M. Hong. 2017. China-Pakistan economic corridor and its social implication on Pakistan: How will CPEC boost Pakistan's infrastructures and overcome the challenges? Art Social Science Journal 8 (2).

Ahmad, Waqar. 2015. Balochistan, CPEC another view. Islamabad: The Daily Times.

Ali, Akber. 2016. China Pakistan economic corridor: prospects and challenges for regional integration. Arts and Social Sciences Journal 7: 4

Ali, L., M. Jianing, M. Shah, A. Khan, and M. Imran. 2017. Transport culture akin to China Pakistan economic corridor. Journal of Human System Management, (In Press). https://doi.org/10.3233/HSM-17111.

Arif, M. 2015. CPEC to be guarantor of future Progress, Unity of Federation of Pakistan: Senator Mushahid. Retrieved 1121 , 2015, from http://www.pakistan-china.com/newsdetail.php?id=NTE2\&pageid=news.

Beenish, S. 2013. Rejuvenating Pakistan's standing: benefitting from China's rise. NDU Monograph 4 (3).

Bhattacharjee, D.D. 2015. China Pakistan economic corridor (CPEC). Issue Brief. Delhi: Indian Council of World Affairs.

Bhutta, Zafar. 2015. India bid to halt Pakistan projects fails. The Express Tribune.

Bilal, M. 2014. Pak-China economic corridor: Geo-strategic importance of Pakistan. Policy Research Institute of Market Economy. Blah, M. 2018. China's belt and road initiative and India's concerns. Strategic Analysis 42 (4): 313-332.

Byman, D., and J. Lind. 2010. Pyongyang's survival strategy: Tools of authoritarian control in North Korea. International Security 35 (1): 44-74.

Chaudhri, M. A. 1987 Strategic and military dimensions in Pakistan-China relations' in Pakistan and world society. Karachi: Royal Book Company, 2(17), 67-94.

Cherng, S, Ouyang. 2013. The Sino-Pak Trade and Energy Corridor- An Assessment, 8th Pan- European Conference on International Relations. Warsaw Economics University, 21 September 2013.

Choi, J., and M. Shaw. 2010. The rise of Kim Jong Eun and the return of the party. International Journal of Korean Unification Studies 19 (2): 175-202.

Chowdhury, D. R. 2013. Pakistan happy to aid in China's quest for land route to the west: India, Not So Much. South China Morning Post.

Dawn. 2014. Sherpao opposes change in Pak-China economic corridor route. Karachi.

Dawn. 2015. 'Pakistan, Russia Sign Agreement for Construction of North south Gas Pipeline'. Dawn (October 16). Available at http://www.dawn.com/news/1213460. Accessed 23 Dec 2016.

De, P., and K. lyengar. 2014. Developing economic corridors in South Asia. Asian Development Bank.

Dent, C.M. 2016. East Asian regionalism. Routledge.

Dhaka, A. 2014. Factoring Central Asia into China's Afghanistan policy. Journal of Eurasian Studies 5 (1): 97-106.

Disk, N. 2017. CPEC: How Much Annual Revenue Pakistan Will Earn. Retrieved from https://timesofislamabad.com/cpechowmuch-annual-revenue-pakistan-will-earn/.

Durrani, S. 2013. The Kashgar-Gwadar corridor. Karachi: The News.

Fallon, T. 2015. The new silk road: Xi Jinping's grand strategy for Eurasia. American Foreign Policy Interests 37 (3): 140-144. https://doi.org/10.1080/10803920.2015.1056682.

Haider, M. and I. Haider. 2015. Economic corridor in focus as Pakistan. China sign 51 MoUs. Retrieved from https://www. dawn.com/news/1177109/economic-corridor-in-focus-as-pakistan-china-sign-51-mous. Accessed 11 Dec 2015.

Hameed, M. 2018. The politics of the China_Pakistan economic corridor. Palgrave Communications 4 (1): 64.

Hancock, T. 2017. China missionaries seek converts along the belt and road. Financial Times, August 11. https://www.ft.com/ content/69a41f7e-6b96-11e7-bfeb-33fe0c5b7eaa.

Holmes, J. R. 2013. Gwadar and the "String of Pearls". The Diplomat, 9.

Huasheng, Z. 2016. Afghanistan and China's new neighbourhood diplomacy. International Affairs 92 (4): 891-908.

Irshad, M. S. (2015). One belt and one road: dose China-Pakistan economic corridor benefit for Pakistan's economy?. Journal of Economics and Sustainable Development, 6(24).

Javaid, U. \& Jahangir, A. (2015). Pakistan-China strategic relationship: A glorious journey of 55 years. Journal of the Research Society of Pakistan,52(1).

Jabri, P. 2015. CPEC projects to benefit all provinces of Pakistan: Chinese envoy. Associated press of Pakistan.

Jain, R. 1981. China south Asian relations, 1947 1980. New Delhi: Radiant.

Javaid, U., and A. Jahangir. 2015. Pakistan-China strategic relationship: a glorious journey of 55 years. Journal of the Research Society of Pakistan 52 (01): 157-183.

Jinchen, T. 2016. One belt and one road': connecting China and the world. Global Infrastructure Initiative website.

Kabraji, R. 2012. The China-Pakistan Alliance: Rhetoric and limitations. Chatham House Asia Program.

Khan, S. A. (2013). Geo-economic imperatives of Gwadar Sea Port and Kashgar economic zone for Pakistan and China. IPRI Journal, 13(2), 87-100. Imperatives of Gwadar Sea Port and Kashgar Economic Z, https://www.ipripak.org/wp-content/ uploads/2014/02/art5sha.pdf

Khan, A.U. 2015. Pak-China economic corridor: The hopes and reality. Spotlight: Institute of Regional Studies. 
Khan, N. A. 2018. Pakistan, Tajikistan and CPEC. Retrieved from Pakistan Observer: https://pakobserver.net/pakistantajikistan-and-cpec/.

Khan, S.A. 2013. Geo-economic imperatives of Gwadar Sea port and Kashgar economic zone for Pakistan and China. IPRI: 93-95.

Kostecka, D.J. 2011. Places and bases: the Chinese navy's emerging support network in the Indian Ocean. Naval War College Review 64 (1): 59-78.

Kumar, Vinod, and A.K. Chopra. 2009. Impact of climate change on biodiversity of India with special reference to Himalayan region - An overview. Journal of Applied and Natural Science 1 (1): 117-122.

Lee, S.S. 2012. Paradox of neoliberalism: Arab Spring's implications on North Korea. North Korean Review 8 (1): 53-66.

Liangyu. 2018. Xinhua net. Retrieved from XinhuaNet.com: http://www.xinhuanet.com/english/2018-03/30/c_137076268.htm.

Lim, A. C. H. 2017. The China-Pakistan economic corridor two years on. IPP Review, May 29. http://ippreview.com/index.php/Blog/ single/id/449.html.

Malik, Hasan Yaser. 2012. Strategic Importance of Gwadar Port. Journal of Political Studies 19 (2): 57.

Mangi, F., and Haider, K. 2015. China Superhighway to Run Through Pakistan-Occupied Kashmir. http://www.livemint.com/ Politics/1BSPn5G8USunbmlbVOgVdl/Chinasuperhighway-to-run-through-Pakistanoccupied-Kashmir.html.

Memoona, et al. 2014. The growing economic ties between Pakistan and China and its impact on the economy of Pakistan. Impact International Journal of Research In Humanities, Arts And Literature 2 (12): 49-54.

Mengal, S. 2016. CPEC route controversy: Problems and opportunities. Bi-annual research journal. Balochistan Review Balochistan study Centre, University of Balochistan, Quetta 35 (2).

Mezzera, M. 2011a. The nature of a friendship: Making sense of Sino-Pakistani relations. Nonwegian Peacebuilding Resource Centre.

Mezzera, Marco. 2011 b. The nature of a friendship: Making sense of Sino-Pakistani relations. Norwegian Peacebuilding Resource Centre, 27 September 2011. http://www.peacebuilding.no/Regions/Asia/Pakistan/Publications/The-nature-of-afriendshipmaking-sense-of-Sino-Pakistani-relations.

Ministry of Planning, D. A (2015). MoU on CPEC. Ministry of Planning, D. a. (n.d.). CPEC. Retrieved November 12, 2015, from http://www.pc.gov.pk/?page_id=2731.

Muhammad, S.I., and X. Qi. 2015. Rising trend in imports and exports of Pakistan's FTA Partners in recent years. Academic Research International 6 (4): 1-19.

Mezzera, M. (2011). The nature of friendship: making sense of Sino-Pakistani relations. NOREF Policy Brief, 27.

Mustafa, F., A. Khursheed, and M. Fatima. 2018. Impact of global financial crisis on financially innovative microfinance institutions in South Asia. Financial Innovation 4 (1): 1-11.

Ge Nan. 2015. Opening Ceremony of the International Academic Symposium on CPEC. Office of International Relations, Peking University, 24 May 2015. http://www.oir.pku.edu.cn/En/html/2015/NewsExpress_0524/280.html.

News, T. 2014. Third meeting of JCC on China Pakistan economic corridor held.

Nogales, E.G. 2014. Making economic corridors work for agricultural sector. Food and Agriculture Organization of The United Nations.

Park, HJ. 2011. Political dynamics of hereditary succession in North Korea. International Journal of Korean Unification Studies 20 (1): 1-30.

Peter-Brunner, H. 2013. What is economic corridor development and what can it achieve in Asia's subregion. Asian Development Bank 1 (3): 2-17.

Ramachandran, P., and L. Linde. 2011. Integrating spatial support tools into strategic planning -SEA of the GMS north-south economic corridor strategy and action plan. Environmental Impact Assessment Review 31 (6): 602-611.

Rasul, Golam. 2014. Food, water, and energy security in South Asia: A Nexus perspective from the Hindu Kush Himalayan region. Environmental Science \& Policy 39 (4): 35-48.

Raza, M. 2016. Coal plant project likely to be shifted after govt-Kapco disagreement. Dawn, [online]. Available at: https:/www. dawn.com/news/1245764/coal-plant-project-likely-to-be-shifted-after-govt-kapco-disagreement.

Reform, M. o. 2015. Background of CPEC Affairs, and Ministry of Commerce of the People's Republic of China, with State Council authorization.

Rind, H.M. 2013. Tender sought for Gwadar Ratodero road. Karachi: The News.

Ritzinger, L. 2015. The China-Pakistan economic corridor regional dynamics and China; s geopolitical ambitions. Vol. 16. The National Bureau of Asian Research. Strategic Asia.

Rizvi, H.A. 2013. China and Pakistan's economic recovery.

Seerat, R. A. 2019. China's role in afghan-Taliban peace talks: Afghan perspectives. Institute of Chinese Studies. Erişim Adresi: https:/www.icsin.org/uploads/2015/08/24/6f949b585a51f6f4fd06226212c951aa.pdf. Erişim Tarihi, 5.

Shah, S. 2015. China's xi Jinping launches investment Deal in Pakistan. The Wall Street Journal. Available at: http://www.wsj.com/ articles/chinas-xi-jinping-set-to launch-investment-deal-in-Pakistan-1429533767.

Shehzad, A. 2018. CPEC. Retrieved from CPEC Official: http://cpec.gov.pk/.

Sial, S. 2014. The China-Pakistan economic corridor: An assessment of potential threats and constraints. Conflict and Peace Studies 6 (2): 11-40.

Siddiqui, S. 2017. CPEC investment pushed from $\$ 55 b$ to $\$ 62 b$. Express Tribune, April 12. https://tribune.com.pk/story/1381733/ cpec-investment-pushed-55b-62b/.

Stares, P., and J. Wit. 2009. Preparing for sudden change in North Korea. Washington DC: Council on Foreign Relations http://www.cfr.org/content/publications/attachments/North_Korea_CSR42.pdf.

Syed, et al. 2014. Compulsions of Sino-Pakistani strategic engagement in lieu of security constraints engendered by the anarchistic international political system. A Research Journal Of South Asian Studies 29 (2): 597-610.

Team, R. 2015. Impact of China-Pak economic corridor. A Bird Eye's View. BMA Capital.

Tharoor, I. 2015. What China's and Pakistan's special friendship means? The economist time, 2014. Nawaz Sharif, Li. Retrieved from https:/www.washingtonpost.com/news/worldviews/wp/2015/04/21/what-china-and-pakistans-special-friendshipmeans/. Accessed 10 June 2017.

Tiezzi, Shannon. 2014. China, Pakistan flesh out new „economic corridor. The Diplomat, February 20th, 2014. http:// thediplomat.com/2014/02/china-pakistan-flesh-out-new-economic-corridor/. Accessed 18 Nov 2015.

Tsan, K.F. 2012. Re-energizing the Indian-Russian relationship: Opportunities and challenges for the 21st century. Jindal Journal of International Affairs 2 (1): 141-184.

Vaughn, B. and Morrison, W. 2006. China Southeast Asia relations: Trends, issues, and implications for the United States. Congressional Research Service. The Library of Congress. 
Wang, J. 2015. China's 'new silk road: a case study in Eu-China relations. In Xi's policy gambles: the bumpy road ahead, ed. A. Amighini and A. Berkofsky, 92-109.

Wheeler, D. B. 2017. LUMS. Lahore. https://lums.edu.pk/news/general-news/dr-bob-wheelerdiscusses-pros-and-cons-cpec. Wolf, O.S. 2012. The Good Neighbor: China's Alternative Strategy in Afghanistan. In The China- Pakistan Economic Corridor: An Assessment of its Feasibility and impact on Regional Cooperation, South Asia Democratic Forum (SADF), ed. O.S. Wolf, 1-63.

Wolf, O.S. 2016. The China- Pakistan Economic Corridor: An Assessment of its Feasibility and impact on Regional Cooperation, South Asia Democratic Forum (SADF), 1-63.

$\mathrm{Xu}$, S. 2015. Vision and actions on jointly building silk road Economic Belt and 21st-century maritime silk road. National Development and Reform Commission, Ministry of Foreign.

Yang, Jian, and Rashid Ahmed Siddiqi. 2011. About an "all-weather" relationship: Security foundations of Sino-Pakistan relations since 9/11. Journal of Contemporary China 20 (71): 563-579.

Yogesh. 2013. Security and Strategic Implications of the Worldometers. Pakistan.

Zaki, M. Akram. 2014. The evolution in global power balance and Pak-China relations. Policy Perspectives 11 (2): 3-18.

Zhang, Jian. 2015. China's new foreign policy under xi Jinping: Towards peaceful rise 2.0. Global Change, Peace \& Security 27 (1): 5-19.

Zubacheva, K. 2016. What's wrong with the Russia-India relationship? Russia direct. Available at http://www.russia-direct.org/ analysis/whats-wrongrussia-india-relationship.

\section{Publisher's Note}

Springer Nature remains neutral with regard to jurisdictional claims in published maps and institutional affiliations.

Submit your manuscript to a SpringerOpen ${ }^{\circ}$ journal and benefit from:

- Convenient online submission

- Rigorous peer review

- Open access: articles freely available online

- High visibility within the field

- Retaining the copyright to your article

Submit your next manuscript at $>$ springeropen.com 